\title{
Comparison of Glycolipid Compositions of NKT Cell Lines with those of NK and T Cells
}

Michio Shimamura

Mitsubishi Kasei Institute of Life Sciences, 11 Minamiooya, Machida, Tokyo 194-8511, Japan

(Received 18 March 1999; and accepted 3 April 1999)

\begin{abstract}
Glycolipid compositions of NK $1.1^{+} \mathrm{TCR} \alpha \beta^{+} \mathrm{T}$ (NKT) cell lines were analyzed to predict the cell lineage of NKT cells. NKT cell hybridomas produced by fusion of mouse thymic NKT cells with thymoma, BW5147, either with or without $\mathrm{V} \alpha 24-\mathrm{J} \alpha 281$ rearrangement in their $\mathrm{T}$ cell receptor genes were metabolically labeled with $\left[{ }^{14} \mathrm{C}\right]$-galactose and -glucosamine hydrochloride and their glycolipid compositions were examined by high performance thin layer chromatography. Several glycolipid components that were helpful for diagnosis were found in the NKT cell lines. They expressed components specific for natural killer (NK) and/or cytotoxic T cells. Expression of asialogangliotetraosylceramide $\left(\mathrm{AsGM}_{1}\right)$, a typical NK cell marker, was also helpful for the diagnosis. As the expression of $\mathrm{AsGM}_{1}$ in the NKT cell hybrids were not enough for the quantitative analysis by TLC, mouse liver NKT, conventional $\mathrm{T}$ and $\mathrm{NK}$ cells ex vivo were analyzed for the comparison of $\mathrm{AsGM}_{1}$ level by means of immunofluorescence flow cytometry. The average of $\mathrm{AsGM}_{1}$ expression in the NKT cells was much less than that in the classical NK cells but was slightly higher than that in the conventional $\mathrm{T}$ cells. Taken together, glycolipids remarkable in both $\mathrm{T}$ and NK cells were observed in the NKT cell lines, suggesting that NKT cells diverge between NK and T cells during ontogeny as predicted by the analyses of their cell surface markers so far reported.
\end{abstract}

$\mathrm{NK} 1.1^{+} \mathrm{TCR} \alpha \beta^{+} \mathrm{T}(\mathrm{NKT})$ cells are a newly characterized subset of mature cells that coexpress marker molecules for both $\mathrm{T}$ and $\mathrm{NK}$ (natural killer) cells including each antigen receptor $(4,6,19,31)$. NKT cells express a very limited TCR repertoire with an invariant $\alpha$-chain (V $\alpha 14-\mathrm{J} \alpha 281)(18,21)$ and three frequently used $\mathrm{V} \beta$ domains $(\mathrm{V} \beta 8,7$ and 2$)(2)$, and this

Abbreviations: NK, natural killer; NKT, $\mathrm{NK} 1.1^{+} \mathrm{TCR} \alpha \beta^{+} \mathrm{T} ; \mathrm{AsGM}_{1}$, asialogangliotetraosylceramide $\left(\mathrm{Gg}_{4} \mathrm{Cer}\right)$; CTL, cytotoxic Tlymphocyte; $\mathrm{NK}$, natural killer ; $\gamma_{\mathrm{c}}$, common cytokine receptor $\gamma$; $\mathrm{mAb}$, monoclonal antibody; HPTLC, high performance thin layer chromatography

Correspondence to: Dr M. Shimamura at the above address.

Tel: +81-42-724-6235; Fax: +81-42-724-6316;

E-mail:michio@libra.1s.m-kagaku.co.jp restricted TCR repertoire is considered to recognize a conserved ligand composed of the nonpolymorphic CD1 (5). On the other hand NKT cells are capable of being induced to kill tumor cells in the same manner as classical NK cells after exposure to cytokines such as IL-2 , IL-4 and IL-12 in vitro $(3,15,30)$. NKT cells exhibit distinct responses toward stimulation through $\mathrm{T}$ and NK cell receptors; when their TCRs are cross-linked by anti-CD3 monoclonal antibody (mAb), they secrete both IL-4 and IFN$\gamma$, whereas upon exposure to anti-NK1 antibodies, they produce IFN- $\gamma$ but no IL-4 (1). This particular feature of them provide a hypothesis that NKT cells may play important roles in immune regulation such as Th1, Th2 cell differentiation. Collectively, these findings on NKT cells suggest that they possess characteristics for both $\mathrm{T}$ 
and NK cells in addition to those of their own. However, the cell lineage of NKT cells is not clearly understood.

Glycoconjugates are one of the major cell membrane components and have been implicated in a number of functions involved in cell - cell interaction, cell proliferation and cell recognition $(11,31)$. Moreover, several glycolipids have been reported to be a convenient marker to predict a lineage of lymphoid cells, for example, asialogangliotetraosylceramide $\left(\mathrm{AsGM}_{1}\right)$ for murine $\mathrm{NK}$ cells $(14,33), \mathrm{GM}_{1 \mathrm{~b}}$ for $\mathrm{T}$ cell blast $(22), \mathrm{GD}_{1 \alpha}$ and $\mathrm{GD}_{1 \mathrm{c}}$ for Th1 cells $(9,23)$, and $\mathrm{GD}_{\mathrm{la}}$ for Th2 cells (9).

In this study, the glycolipid compositions of cloned T-T hybrids derived from NKT cells (26) were analyzed and were compared with those of $T$ and NK cells to predict the cell lineage of NKT cells.

\section{MATERIALS AND METHODS}

Mice,

C57BL/6 and scid/scid on BALB/c background mice were purchased from Japan SLC Inc. (Japan).

Cells.

Thymic NKT cell hybridomas, produced by fusion with BW5147 thymoma (7) as previously described (26), were given by Drs H. R. MacDonald and $T$. Ohteki (Ludwig Institute for Cancer Research, Lausanne Branch). A cytotoxic T cell clone, OE4 (28), and a thymoma, EL4 (10), derived from C57BL/ 6 mice were presented by $\mathrm{Dr}$ H. Takayama (Mitsubishi Kasei Institute of Life Sciences). NK cells were prepared from fetal liver of BALB/c (scid/scid) mice as described by Orihuela et al. (25). Briefly, nylon wood nonadherent fetal liver mononuclear cells were cultured in the medium supplemented with the culture supernatant of PMA-stimulated EL-4 cells (10\%) for 3 days. The cells strongly adhered to the plastic substratum were removed by panning and the resultant cells were cultured for 3 more days and used for metabolic labeling.

\section{Metabolic labeling and fractionation of cells.}

Cells of several lines and NK cells in the primary culture $\left(1 \times 10^{7}\right)$ were labeled with $\left[1-{ }^{14} \mathrm{C}\right]-\mathrm{Gal}(1$. $9 \mathrm{GBq} / \mathrm{mmol}$, Du Pont NEN, USA) and $\left[1-{ }^{14} \mathrm{C}\right]-$
$\mathrm{GlcNH}_{2}-\mathrm{HCl}(1.9 \mathrm{GBq} / \mathrm{mmol}$, Du Pont NEN) at a concentration of $37 \mathrm{kBq} / \mathrm{mL}$ in a glucose-free DMEM (Gibco BRL, USA) supplemented with $10 \%$ FCS for $18 \mathrm{~h}$. For the labeling of OE4 and NK cells, the culture supernatant of EL4 (10\%) was also added to the medium. Cells were washed twice with Hanks' balanced salt solution, once with PBS, then extracted with chloroform/methanol $(2: 1$ and $1: 2)$ sequentially as described previously (27). Glycolipids in the extracts were analyzed by high-performance thin-layer chromatography (HPTLC) (Kiesel gel 60, Merck, Germany) after removal of neutral lipids by wash with n-hexane. Immunostaining of TLC plates were done as reported (13). The residues were used to analyze the glycoprotein compositions by SDS-polyacrylamide gel electrophoresis (PAGE) under the conditions of Laemmli (16).

IL-4 assay. Cells $\left(10^{4}\right)$ were placed on a 96 well plastic plate precoated with anti-CD3 antibodies (2C11, 0.1 and $1 \mu \mathrm{g} / \mathrm{mL})$ (19) and cultured for $48 \mathrm{~h}$. Culture supernatants were analyzed for the production of IL-4 using an ELISA kit (Endogen, USA).

Immunofluorescence staining of liver cells and flow cytometric analysis.

C57BL/6 liver lymphoid cell fraction was prepared as previously described (24). Briefly, livers were pressed through stainless steel mesh and suspended in DMEM. Cells were washed once with DMEM, then fractionated by discontinuous (40 and $80 \%$ ) Percoll gradient centrifugation for $10 \mathrm{~min}$ at $900 \mathrm{~g}$. The interface was harvested and washed with DMEM including 5\% FCS and use for immunofluorescence staining. Cells were immunostained on ice in Hanks' balanced salt solution supplemented with $3 \%$ FCS and $0.025 \%$ sodium azide. Flow cytometric analysis was conducted with a FACScan and the CELL Quest program (Becton Dickinson, USA). The following $\mathrm{mAbs}$ were used: H57-597-PE (anti-TCR C $\beta$; Caltag Laboratories, USA), PK136-biotin (antiNK 1.1; Pharmingen), rabbit anti-AsGM antiser- $_{1}$ um (Wako Pure Chemical Industries, Japan) and goat anti-rabbit IgG-FITC (Vector Laboratories, USA). Biotin-labeled antibodies were developed by streptanidin-labeled Tri-color (Caltag Laboratories). 


\section{RESULTS}

It is of great interest to determine the cell lineage of NKT cells, belonging to a newly discovered T cell repertoire characterized by the expression of both T and NK cell surface markers $(4,6,19,31)$. To address further this question, cell lines derived from NKT cells were analyzed with regard to their glycoconjugate compositions to compare them with those of $\mathrm{T}$ and NK cells. In Table $I$ are summarized the cell lines used for the present study. Six representative hybridomas derived from thymocytes with a phenotype of $\mathrm{NK} \cdot 1^{+}$, TCR $\alpha \beta^{+}$, were used, all of them except for RT8 have a TCR $\alpha$ chain with a canonical sequence $(\mathrm{V} \alpha 14-\mathrm{J} \alpha 281)(18,21)$ characteristic for NKT cells, although their $\mathrm{V} \beta$ usage is different $(\mathrm{V} \beta 8$ or $\mathrm{V} \beta 2$ ), whereas RT8 has a TCR $\alpha$ chain with a rearrangement other than $V_{\alpha} 14 \quad((26)$ and this study). Although they have different TCRs, all possess a potency to secrete IL-4 following stimulation to their TCR as shown in Fig. 1, thus suggesting that a functional feature characteristic for NKT cells is preserved in the most of the hybridomas. RT21 is less responsive to stimulation through TCR in spite of its possession of a $\mathrm{TCR} \alpha$ chain with $\mathrm{V} \alpha 14-\mathrm{J} \alpha 281$ rearrangement, but its transcription was less than others in the

Table I Cell lines used in this study

\begin{tabular}{llccc}
\hline & Cell lines & $\mathrm{V} \alpha{\text { 14-J } \alpha 281^{\text {a) }}}$ & $\mathrm{V} \beta^{\text {b) }}$ & Reference \\
\hline RT2 & thymic NKT cell hybridoma & + & 8 & 26 \\
RT5 & thymic NKT cell hybridoma & + & 8 & 26 \\
RT8 & thymic NKT cell hybridoma & - & 8 & 26 \\
RT21 & thymic NKT cell hybridoma & + & 8 & 26 \\
RT23 & thymic NKT cell hybridoma & + & 8 & 26 \\
RT24 & thymic NKT cell hybridoma & + & 2 & 26 \\
BW5147 & thymic T lymphoma & - & - & 7 \\
OE4 & cytotoxic T cell clone & - & 8 & 28 \\
EL4 & thymic T lymphoma & - & nd & 10
\end{tabular}

a) TCR gene $V_{\alpha} 14-J \alpha 281$ rearrangement

b) Surface expression of TCR V $\beta,-$, absence of surface expression of TCR molecules nd, not determined
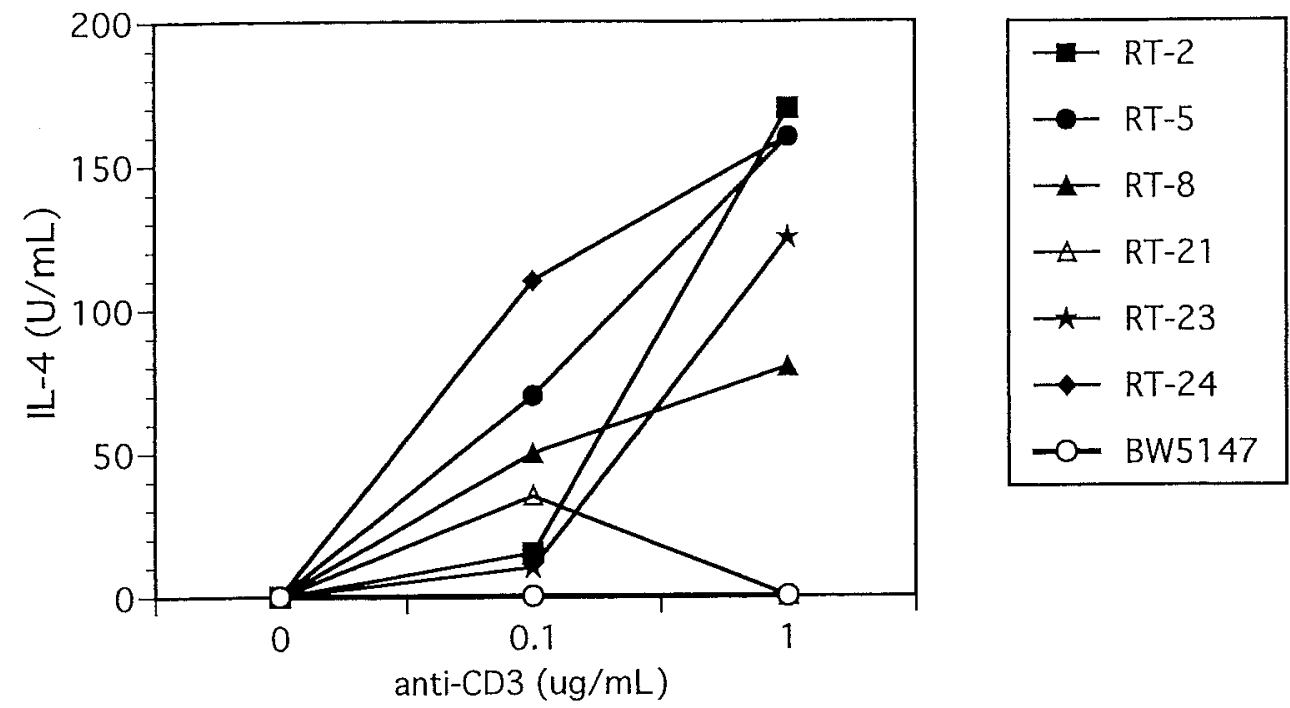

Fig. 1 IL-4 production of NKT cell hybridomas following stimulation with anti-CD3 mAb (2C11). Cells were cultured for $48 \mathrm{~h}$ on a plastic plate pre-coated with anti-CD3 $\mathrm{mAb}(0.1$ and $1 \mu \mathrm{g} / \mathrm{mL})$, and the culture supernatants of the cells were assayed for IL-4 by ELISA. Recombinant IL-4 was used for the standard. 
analysis by RT-PCR method (data not shown). OE4 and EL4 cells were used as references for T cells, and primarily cultured NK cells isolated from lymphocyte-deficient mice (scid mice) were used for the reference of NK cells since no appropriate NK cell lines were available.

These cells were extracted with the mixture of chloroform and methanol $(2: 1$ and $1: 2)$ and the extracts were used for the analysis of their glycolipid compositions. Fig. 2 shows HPTLC analyses of glycolipids expressed by the NKT cell hybridomas and their referential cell lines. Several components (numbered in the figure) that were absent in the parental cell line, BW5147, were helpful for diagnosis of the cell lineage of the original NKT cells fused with BW5147, although identification of these glycolipid species were difficult in some cases because of the discord of their Rf values to those of the references isolated from bovine brain (for gangliosides) and porcine blood cells (for neutral glycolipids) on the HPTLC analysis. The expression of the component 1 (just lower than Gb4) and 3 (near to GM1) was remarkable in the NK cells, and both components were shared by all the NKT cell lines. The component 4 that was augmented in a cytotoxic $\mathrm{T}$ cell clone, OE4, was expressed by RT5, 21, 23 and 24, but was slightly found in RT2 and 8 . On the other hand the distribution of the component 5 characteristic for a $\mathrm{T}$ lymphoma, EL4, was reciprocal to that of the component 4. These observations suggest that NK $\mathrm{T}$ cells are apparently heterogeneous in terms of not only TCR V usage but also of glycolipid expression.

An attention was then paid to examine the expression of $\mathrm{AsGM}_{1}$ in these NKT cell lines since it is known that this neutral glycosphingolipid is constitutively expressed in a large amount in NK cells $(14,33)$ but not so much in $T$ cells except for in those in an activated state (29). Expression of $\mathrm{AsGM}_{1}$ analyzed by a immunostaining of a TLC plate was observed in the NK and OE4 cells that had been activated with IL-2, but its expression was only detectable after longer exposure of the TLC plate in the NKT cell lines and also even in a LGL-like NK clone, SPB2.4 (12) (data not shown). To get more information on the expression of $\mathrm{AsGM}_{1}$ in NKT cells, they were freshly prepared from $\mathrm{C} 57 \mathrm{BL} / 6$ adult livers and were analyzed for the expression of the glycolipid by flow cytometry. Fig. 3 shows the expression of $\mathrm{AsGM}_{1}$ in classical NK (TCR $\alpha \beta^{-}$ NK $\left.1.1^{+}\right)$, NKT $\left(\mathrm{TCR} \alpha \beta^{+}\right.$NK $\left.1.1^{+}\right)$, conven- tional T (TCR $\left.\alpha \beta^{+} \mathrm{NK} 1.1^{-}\right)$and $\mathrm{TCR} \alpha \beta^{-} \mathrm{NK} 1.1^{-}$ cells. Most NKT and conventional $\mathrm{T}$ cells were dull positive and only a part of these cells were brightly stained as NK cells were, although the average level of AsGM1 expression in NKT cells was slightly higher than that in conventional $\mathrm{T}$ cells, suggesting that NKT cells are near to conventional $\mathrm{T}$ cells in terms of the expression of $\mathrm{AsGM}_{1}$.

The residues obtained during the chloroformmethanol extraction of the cells labeled with $\left[{ }^{14} \mathrm{C}\right]$-Gal and $-\mathrm{GlcNH}_{2}-\mathrm{HCl}$ were used for the analysis of glycoproteins by SDS-PAGE, and it was found that the expression patterns of glycoproteins in the NKT cell hybridomas were apparently similar to each other, and the components found in them were almost shared by BW5147, indicating that their glycoprotein compositions were less informative than their glycolipid compositions (data not shown).

\section{DISCUSSION}

Although biological functions of glycoconjugates are not fully understood, it has been known that alteration of glycoconjugate compositions sometimes well reflect physiological changes or progress of cell differentiation. Particularly, compositional changes of glycolipid rather than glycoprotein are facile to detect because glycoproteins highly associated to certain physiological function are generally minor components and changes in their amounts are masked by other large amount of house-keeping components. Glycoconjugate compositions of NKT cell hybridomas (26) were analyzed in this study since this strategy is only available at present to obtain some informations on the compositions of such a newly characterized T cell repertoire, NKT cell, in a clonal level. As shown in Figure 2 (d), the NKT cell lines contain components remarkable to NK and/or T cells, thus suggesting that NKT cells are developmentally divided from a different between $\mathrm{T}$ and NK lineage. In addition, component 2 and 6 were found to be uniquely expressed by the NKT cell lines, implying that NKT cells were located at their own status in the lymphocyte lineage.

There seemed to be no apparent relationship between glycolipid composition and either TCR structure (Table I), CD4 expression (RT2, 23 and 24 are CD4 negative and RT5, 8 and 21 are CD4 positive (26) ) or preserved potency to secrete IL-4 

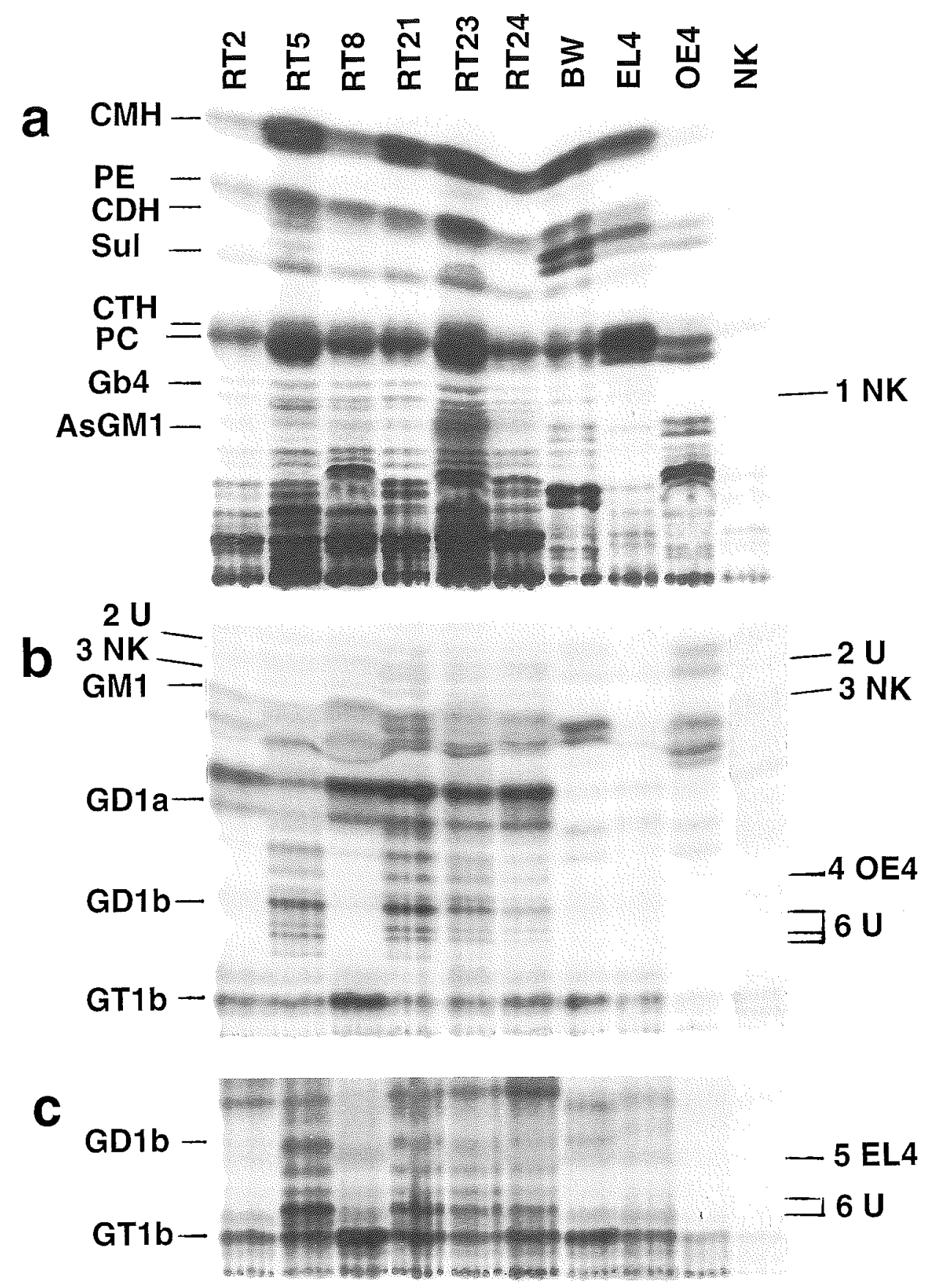

Fig. 2 Glycolipid composition of NKT cell hybridomas. Glycolipids metabolically labeled with [ $\left.{ }^{14} \mathrm{C}\right]-\mathrm{Gal}$ and $\mathrm{GlcNH} \mathrm{NH}_{2} \mathrm{HCl}$ were analyzed by HPTLC (Kieselgel 60). The HPTLC plate was developed in the mixture of chloroform, methanol and water including $0.02 \% \mathrm{CaCl}_{2}$ ((a) $65: 35: 8$, (b) $50: 45: 10$, (c) $55: 40: 10$, and the components were visualized by an image analyzer (Bas 2,000, Fuji Film Co., Japan). NKT cell hybrid cell lines, RT2, RT5, RT8, RT21, RT23, RT24, their fusion partner, BW5147, NK cells in the primary culture, thymoma, EL4 and CTL clone, OE4, were analyzed. Abbreviations: CMH, ceramide monohexoside; PE, phosphatidylethanolamine; CDH, ceramide dihexoside; Sul, sulfatide; PC, phosphatidylcholine; CTH, ceramide trihexoside; Gb4, globotetraoside ceramide. (d) The expression of diagnostic components in the NKT cell lines are summarized. Abbreviations: OE4, EL4, or NK, glycolipids that are expressed in OE4, EL4 or NKcells but are absent in BW5147; U, components unique for the NKT cell lines. Note that not only glycolipids but also phospholipids were labeled with $\left[{ }^{14} \mathrm{C}\right]-\mathrm{Gal},-\mathrm{GlcNH} \mathrm{N}_{2}$ and their metabolites under the present labeling conditions. 
(d)Expression of diagnostic glycolipid components

\begin{tabular}{|c|c|c|c|c|c|c|}
\hline Diagnostic components & RT2 & RTS & RT8 & RT21 & RT23 & RT24 \\
\hline $1 \mathrm{NK}$ & + & + & + & + & + & + \\
\hline $2 U$ & + & + & + & + & + & + \\
\hline $3 \mathrm{NK}$ & + & + & + & + & + & + \\
\hline $4 \mathrm{OEA}$ & & + & & + & + & + \\
\hline $5 \mathrm{EL} / 4$ & + & & + & & & \\
\hline $6 \mathrm{U}$ & & + & & + & + & + \\
\hline
\end{tabular}

in the NKT cell lines. One possible interpretation of these data may be that thymic NKT cells in the criteria of the phenotype (TCR $\alpha \beta^{\text {low }}, \mathrm{NK} 1.1^{+}$) and the responsiveness to $\mathrm{IL}-7$ are positively selected by a common ligand (CD1 + an antigen) and originally possessed a common glycolipid composition irrespective of their TCR V-(D) -J usage and CD4 expression, and after fusion with BW5147, some chromosomes have been lost in RT2 and 8 on which several genes for glycosylation enzymes are coded.

Another key to predict the cell lineage of NKT cells was given by the analysis of the expression of $\mathrm{AsGM}_{1}$ in NKT cells prepared from mouse livers (Fig. 3). NKT cells ex vivo showed much less constitutive expression of $\mathrm{AsGM}_{1}$ than classical NK cells did but on an average they expressed slightly more AsGM (peaked at the 120th channel of the fluorescence intensity in the FACS analysis) than most conventional $\mathrm{T}$ cells (peaked at the 70th) did except for the cells in a small peak at about the 600th channel (these cells were presumably in an activated state (29)). This observation also implies that NKT cells are characterized as cells in a lineage between $\mathrm{T}$ and $\mathrm{NK}$ cells. AsGM 1 has long been known as a cell surface marker for NK cells $(14,33)$, although its biological significance is not clear. Chen et al. reported that the activation of a cell membrane $\mathrm{T}$ cell specific neu-1 sialidase is required for the generation of IL-4 in spleen $\mathrm{T}$ cells following TCR-mediated signaling which results in the increase of the amount of membrane $\mathrm{AsGM}_{1}(8)$. It may thus be possible to speculate that high expression of $\mathrm{AsGM}_{1}$ in $\mathrm{NK}$ cells is maintained by a constitutive activation of a NK cell specific membrane sialidase so far unidentified. A slight increase of the basal level of $\mathrm{AsGM}_{1}$ observed in the liver NK T cells might be due to the limited function of such a NK cell specific sialidase.

Recently, Lantz et al. found a new thymic $\mathrm{T}$ cell population in mice deficient for the common cytokine receptor $\gamma\left(\gamma_{c}\right)$. These T cells expressed the $\mathrm{V} \alpha 14-\mathrm{J} \alpha 281$ invariant $\alpha$ chain and were able to secrete IL-4 following TCR engagement but did not co-express the NK markers such as NK1. 1 and Ly49. The presence of this population suggests that the development of NKT cells occurs in a step-wise manner. These cells would get matured and finally possess features of both $T$ and NK cells suppose that they could be given a signal through $\gamma \mathrm{c}(17)$. It seems of great interest to analyze glycolipid compositions of these $\mathrm{V} \alpha 14^{+}, \mathrm{NK} 1.1^{-}$thymic $\mathrm{T}$ cells in such mutant mice, presumably their components are more $\mathrm{T}$ cell-like than the compositions of mature NKT cells are.

\section{Acknowledgements}

The author thanks Drs H. Higashi, H. R. MacDonald, T. Ohteki, H. Takayama and N. Shinohara for providing cell lines and antibodies, and Mrs Y. Murakami for preparation of the manuscript.

\section{REFERENCES}

1. Arase, H., Arase, N. and Saito, T. (1996) Interferon $\gamma$ production by natural killer (NK) cells and NK1.1+ T cells upon NKR-P1 cross-linking. J. Exp. Med. 183, 23912396.

2. Arase, H., Arase, N., Ogasawara, K., Good, R. A., and Onoé, K. (1992) An NK $1.1^{+} \mathrm{CD} 4+8^{-}$single- positive thymocyte subpopulation that express a highly skewed $\mathrm{T}$-cell antigen receptor $\mathrm{V} \beta$ family. Proc. Natl. Acad. Sci. USA 89, 6506-6510.

3. Ballas, Z. K. and Rasmussen, W. (1993) Adult murine $\mathrm{CD}^{-}, \mathrm{CD} 8^{-}$thymocytes contain an NK1.1+, $\mathrm{CD}^{+}$, CD5hi, CD4hi TCR-V $\beta 8^{+}$subset. J. Inmmunol. 150, 17-30.

4. Bendelac, A., Rivera, M. N., Park, S. -H, and Roark, J. H. (1997) Mouse CDI-specific NK1 T cells: development, specificity, and function. Annu. Rev. Immnol. 15, 535-562.

5. Bendelac, A., Lanz, O., Quimby, M. E., Yewdell, J. W., Bennink, J. R. and. Brutkiewicz, R. R (1995) CD1 recognition by mouse $\mathrm{NK} 1{ }^{+} \mathrm{T}$ lymphocytes. Science 268, 863865.

6. Bix, M., and Locksley, R. M. (1995) Natural T cells that co-express NKRP-1 and TCR. J. Immunol. 155, 10201022.

7. Born, W., White, J., O'Brien, R. and Kubo, R. (1988) Development of $\mathrm{T}$ cell receptor expression: studies using $\mathrm{T}$ 

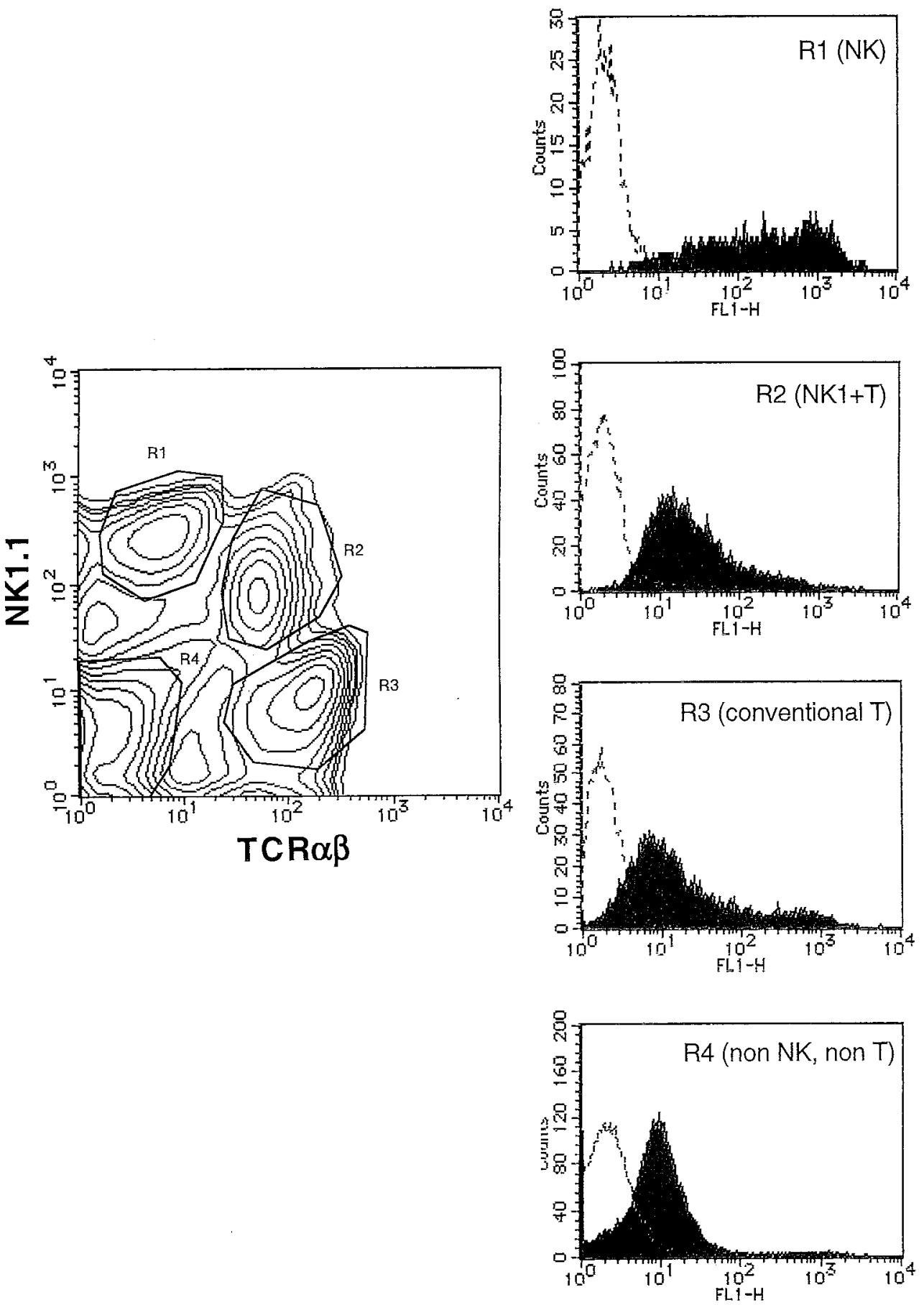

AsGM1

Fig. 3 Expression of $\mathrm{AsGM}_{1}$ in C57BL/6 mouse liver lymphoid cells revealed by a 3 color FACS analysis. Liver lymphoid cells enriched by Percoll gradient were separated into NK cells (Region 1), NKT cells (Region 2), conventional T cells (Region 3) and non NK, non T cells (Region 4) in terms of the expression of NK1. 1 and TCR $\alpha \beta$. The AsGM 1 expression in the cells of each region is shown in the histograms. The negative control level determined by the cells stained only with the FITC-conjugated second antibodies is shown with a broken line in each histogram. 
cell hybridomas. Immunol. Res. 7, 279-291.

8. Chen, X. -P., Enioutina, E. Y. and Daynes, R. A. (1997) The control of IL-4 gene expression in activated murine T lymphocytes. $J$. Immunol, 158, 3070-3080.

9. Ebel, F., Schmitt, E. Peter-Katalinic, J., Kniep, B. and Mühlradt, P. F. (1992) Gangliosides: differentiation markers for murine $T$ helper lymphocyte subpopulation Th1 and Th2. Biochemistry 31, 12190-12197.

10. Farrar, J. J. Fuller-Farrar, J., Simon, P. L., Hilfiker, M. L., Stadler, B. M. and Farrar, W. L. (1980) Thymoma production of $\mathrm{T}$ cell growth factor (interleukin-2). J. Immumol. 125, 2555-2558.

11. Hakomori, S. (1986) Glycosphingolipids. Sci. Am. 254 (5), 32-41

12. Hattori, M., Sudo, T., Izawa, H., Kano, S. and Minato, N. (1989) Developmental regulation of the extrathymic differentiation potential of the progenitor cells for $\mathrm{T}$ cell lineage. Int. Inmunol. 1, 151-159.

13. Higashi, H., Fukui, Y., Ueda, S., Kato, S., Hirabayashi, Y., Matsumoto, M. and Nakai, M. (1984) Sensitive enzyme-immunostaining and densitometric determination on thin-layer chromatography of $\mathrm{N}$-glycolylneuraminic acid-containing glycosphingolipids, Hanganutziu-Deicher antigens. J. Biochem. 95, 1517-1520.

14. Kasai, M., Iwamori, M., Nagai, Y., Okumura, K. and Tada, T. (1980) A glycolipid on the surface of mouse natural killer cells. Eur. J. Immunol.. 10, 175-180.

15. Koyasu, S. (1994) $\mathrm{CD}^{+}, \mathrm{CD} 16^{+}, \mathrm{NK} 1.1^{+}, \mathrm{B} 220^{+}$large granular lymphocytes arise from both $\alpha-\beta$ TCR ${ }^{+} \mathrm{CD}^{-}$, CD8 ${ }^{-}$and $\gamma-\delta \mathrm{TCR}^{+} \mathrm{CD} 4^{--}, \mathrm{CD}^{-}$cells. J. Exp. Med. 179, 1957-1972.

16. Laemmli, U, K. (1970) Cleavage of structural proteins during the assembly of the head of bacteriophage $\mathrm{T} 4$. Nature 227, 680-685.

17. Lantz, O., Sharara, L. I., Tilloy, F., Andersson, A. and DiSanto, J. P. (1997) Lineage relationship and differentiation of natural killer (NK) T cells: Intrathymic selection and interleukin (IL)-4 production in the absence of NKRP1 and Ly49 molecules. J. Exp. Med. 185, 1395-1401.

18. Lantz, A. and Bendelac, A. (1994) An invariant $T$ cell receptor $\alpha$ chain is used by a unique subset of major histocompatibility complex class I-specific $\mathrm{CD}^{+}{ }^{+}$and CD4 ${ }^{-} \mathrm{CD} 8^{-} \mathrm{T}$ cells in mice and humans. J. Exp. Med. 180, $1097-1106$.

19. Leo, O., Foo, M., Sachs, D. H., Samelson, L. E. and Bluestone, J. A. (1987) Identification of a monoclonal antibody specific for a murine T3 polypeptide. Proc. Natl. Acad. Sci. USA 84, 1374-1378.

20. MacDonald, H. R. (1995) NK1.1+ T cell receptor- $\alpha / \beta^{+}$ cells: new clue to their origin, specificity, and function. $J$. Exp. Med. 182, 633-638.
21. Makino, Y., Kanno, R., Ito, T. Higashino, K. and Taniguci, M. (1995) Predominant expression of invariant $\mathrm{V} \alpha 14^{+} \mathrm{TCR} \alpha$ chain in NK $1.1^{+} \mathrm{T}$ cell population. Int. Immunol. 7, 1157-1161.

22. Müthing, J., Egge, H., Kniep, B. and Mühlradt, P. F. (1987) Structural characterization of gangliosides from murine T lymphocytes. Eur. J. Biochem. 163, 407-416.

23. Nakamura, K., Suzuki H., Hirabayashi, Y. and Suzuki, A. (1995) IV3 $\alpha$ (NeuGc $\alpha 2-8 \mathrm{NeuGc}$ )-Gg4Cer is restricted to $\mathrm{CD} 4^{+} \mathrm{T}$ cells producing interleukin-2 and a small population of mature thymocytes in mice. J. Biol. Chem. 270, 3876-3881.

24. Ohteki, T. and MacDonald, H. R. (1994) Major histocompatibility complex I related molecules control the development of $\mathrm{CD} 4^{+} 8^{-}$and $\mathrm{CD} 4^{-} 8^{-}$subsets of natural killer $1.1^{+} \mathrm{T}$ cell receptor $\alpha / \beta^{+}$cells in the liver of mice. J. Exp. Med. 180, 699-703.

25. Orihuela, M., Margulies, D. H. and Yokoyama, W. M. (1996) The natural killer receptor Ly-49A recognizes a peptide-induced conformational determination on its major histocompatibility complex class I ligand. Proc. Natl. Acad. Sci. USA 93, 11792-11797.

26. Shimamura, M., Ohteki, T., Beutner, U. and MacDonald, H. R. (1997) Lack of directed $V_{\alpha}$ 14-J $\alpha 281$ rearrangements in NK1 ${ }^{+}$T cells. Eur. J. Immunol. 27, 1576-1579.

27. Shimamura, M., Oku, M. and Yamagata, T. (1992) A new ganglioside expressed by mouse hematopoietic cell lines. $J$. Biol. Chem. 267, 18810-18813.

28. Staerz, U. D., Kanagawa, O. and Bevan, M. J. (1985) Hybrid antibodies can target sites for attack by $\mathrm{T}$ cells. Nature 314, 628-631.

29. Stout, R. D., Schwarting, G. A. and Suttles, J. (1987) Evidence that expression of asialo-GM1 may be associated with cell activation: correlation of asialo-GMI expression with increased total cellular RNA and protein content in normal thymocyte and spleen cell populations. $J$. Immunol. 139, 2123-2129.

30. Takeda, K. and Dennert, G. (1994) Demonstration of MHC class I specific cytolytic activity in IL-2-activated $\mathrm{NK} 1^{+} \mathrm{CD}_{3}{ }^{+}$cells and evidence of usage of $\mathrm{T}$ and NK cell receptors. Transplantation (Baltimore) 58, 496-504.

31. Varki, A. (1993) Biological roles of oligosaccharides: All of the theories are correct. Glycobiology 3, 97-130.

32. Vicari,, A. P. and Zlotnik, A. (1996) Mouse NK1.1+ T cells: a new family of T cells. Immunol. Today, 17, 71-76.

33. Young, W. W. Jr., Hakomori, S., Durdik, J. M. and Henney, C. S. (1980) Identification of ganglio-Ntetraosylceramide as a new cell surface marker for murine natural killer (NK) cells. J. Inmmunol.. 124, 199-201. 